\title{
An Empirical Investigation Of The Impact Of Exchange Rate Fluctuations On The Performance Of Selected Listed Firms In Nigeria
}

\author{
Harley Tega Williams \\ Redeemer's University, Ede, Osun State, Nigeria, harleytega@yahoo.com
}

\begin{abstract}
This study investigated the impact of exchange rate fluctuations on firm's performance in Nigeria. Having noted the impact of exchange rate fluctuation from the literatures, it become paramount to investigate the impact in the Nigeria context. In this study, seven research questions were formulated which led to the test of seven hypotheses. The major objective of the study was to empirically investigate the impact of exchange rate fluctuations on return of investment. The study makes use of descriptive and ordinary least square methodology. The scope of the study is 2012 to 2016 on a panel data. From the study. The Exchange rate plays a significant impact on Return on Investment as most of the banks are involved in exchange rate transactions. The regression result shows that there is a positive relationship between Return on Investment and exchange rate of 145.4265. This implies that a unit increases in exchange rate of 145.4265 will bring about a rise of 145.4265 in Return on Investment. Since the T-calculated value in the study is 0.287 which is compared to 0.05 i.e $.287>0.05$ we reject the null and accept the alternative hypothesis that there is a significant relationship between exchange rate and return on investment (firm's performance). Other variables used in the study have a positive relationship with return on investment. In the regression result, the coefficient of determination is very high. It shows that about 67 percent of the total variations in Return on Investment (ROI) are explained by all the independent variables in the model.
\end{abstract}

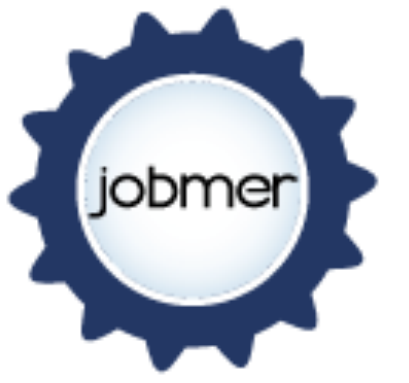

Journal of Business

Management and Economic Research

Vol.2, Issue.3, 2018

pp.1-10

Doi: 10.29226/TR1001.2018.22

Keywords: exchange rate, firm's performance, fluctuation, regression, return on investment 


\section{Introduction}

The impact of exchange rate has a long history in any economy. One of the reasons for the fall of Bretton wood agreements can be traced to the impact of foreign exchange. Most developed nations had in one way or the other guide against exchange rate fluctuations. This implies that the impacts of exchange rate volatility are not a respecter of if a nation is developed or developing. Therefore, at this time where the world is a global village and financial markets are integrated on an online platform, it becomes necessary for nations to put in place strategies that will help in absorbing their exchange rate risk because no nation is isolated from the impact of exchange rate fluctuations.

The impact of exchange rate fluctuations does not only affect country economic activities but also affect the performance of firms in general. An exchange rates fluctuation is also referred to as exchange rate volatility could be described as periods of domestic currency appreciation or depreciation. Calvo and Reinhart (2001) observe that developing countries seem to be more tolerant of foreign reserve fluctuations than exchange rate volatility. This means that as a country experiences exchange rate fluctuations, the authorities use their reserve stock to intervene in the foreign exchange market with the purpose of dampening the exchange rate volatility. This therefore, suggests that the two series may seem to have a long-run relationship. Many empirical works, for example Levy-Yeyati and Sturzenegger (2004) and Calvo and Reinhart (2002) have used reserve volatility as a proxy for intervention. However, this approach has being criticized on the ground that reserve volatility in developing countries cannot be solely attributed foreign exchange transactions, but a number of other factors can cause reserves fluctuations. However, the literature is ambiguous about the direction of the effect of real exchange rate on the level of investment. While a real depreciation of exchange rate raises the cost of imported capital goods, which, in turn, would lead to a fall in domestic investment, a real depreciation arising from raising the firms' performance in the tradable goods sector would stimulate investment in this sector but depress investment in the non-tradable. However, in an economy that is driven by Foreign Direct Investment (FDI) flows and if the capital stock is optima, a real depreciation of the exchange rate will result in a decline in domestic investment.

In Nigeria, the naira exchange rate witnessed a continuous slide in all the segments of the foreign exchange market (that is, official, bureau de change and parallel markets). Given the import dependent nature of the Nigerian industrial sector, the continued depreciation of the naira exchange rate vis-à-vis the currencies of other major trading partners, meant that more resource would be needed to increase domestic output.

A depreciating exchange rate in the absence of domestic sources for input and inadequate infrastructure will raise the cost of production, which will in turn make locally produced goods less competitive compared to the imported counterparts, thus, reversing the benefit of cheaper exports expected from depreciation of any currency. Similarly, the over-dependence of the economy on imported capital goods implies that a depreciating exchange rate would crowd out marginal investment as a result of high investment cost.

The exchange rate is generally regarded as reflecting the worth of an economy in terms of another economy. Foreign exchange is the means of payment for international transactions. It is made up of convertible currencies that are generally accepted for the settlement of international trade and other external obligation. The more the exchange rate depreciates, the lower the value (in real terms) of the goods and services (including salaries and wages of workers) produced in a country vis-à-vis its trading partners. The fact has unfortunately, nationalistic and political colouration to exchange rate management (Nyong, 2005). Those with strong economic 
background and conscious of the need to diversify the Nigerian economy away from oil to nonoil exports will support a depreciating currency which is expected to maintain international competitiveness. However, those with nationalistic and patriotic flavour get uncomfortable and jittery where the exchange rate depreciates against foreign currencies, arguing that it cheapens the economy and makes it easy for foreigners or dominate the domestic economy, thereby perpetrating external dependency. For them, a strong and appreciating currency is considered a source of national pride and aspiration, and is indicative that the economy is doing well. The fluctuation and instability in the exchange rate led to frustration of a lot of firms Nigeria, this therefore make firms that basically source their needed raw material from abroad to be on a shaky ground, even those that source their raw material from the country are indirectly affected due to persistence increase in inflation in the economy at large. This also leads to many import competing firms to increases price in response to foreign competitor rise increases to improve profit margins. It is discovered that most of the literature doesn't offer suggestion on how to hedge against this negative effect of foreign exchange fluctuation on firms. This research work will therefore offer suggestions on how to hedge against exchange rate fluctuation. There are four options to counteract their currency exposure in terms of exchange rate fluctuation. The simplest approach is just to monitor the changes, and this can be the best option if companies do not think that they are at a particularly high risk from exchange rate fluctuations. The main objective of the study is to determine the impact of exchange rate fluctuations on firm performance.

\section{Literatures}

Exchange rate is the price of one country's currency expressed in terms of some other currency. It determines the relative prices of domestic and foreign goods, as well as the strength of external sector participation in the international trade. Exchange rate regime and interest rate remain important issues of discourse in the International finance as well as in developing nations, with more economies embracing trade liberalization as a requisite for economic growth (Owolabi 2017). The impact of foreign exchange rate fluctuations is generally deep on firms and there should be good methods of hedging against it. Hence, an organization needs to do careful analysis of these effects on its operations before making a decision on how to deal with it. This chapter will highlight the theories associated with international transactions and exchange rate systems. It will also review empirical evidence from other similar research work done before in order to conceptualize the study. Therefore, organizations have to evaluate the risks of doing business on an international level. But it doesn't always work in their favour. For instance, McDonald's saw sales in Europe increase in 2011, but the yearly profits were actually down as a result of a weakening euro. Indeed, some experts think investors should be cautious this year too given that the US dollar has strengthened so much recently and is expected to continue doing so. As McDonald's generate nearly three quarters of its profits overseas, this could be an issue if they have not hedged (Adegbite, 2017).

In Nigeria, exchange rate has changed within the time frame from regulated to deregulated regimes. Asher (2016) agreed that the exchange rate of the naira was relatively stable between 1973 and 1979 during the oil boom era and when agricultural products accounted for more than 70\% of the nation's gross domestic products (GDP). In 1986 when Federal government adopted Structural Adjustment Policy (SAP) the country moved from a peg regime to a flexible exchange rate regime where exchange rate is left completely to be determined by market forces but rather the prevailing system is the managed float whereby monetary authorities intervene periodically in the foreign exchange market in order to attain some strategic objectives (Mordi, 
2006 cited in Azeez, Kolopo, \&Ajayi, 2012). This inconsistency in policies and lack of continuity in exchange rate policies aggregated unstable nature of the naira rate (Gbosi, 2005). Benson and Victor, (2012) and Aliyu, (2011) noted that despite various efforts by the government to maintain a stable exchange rate, the naira has depreciated throughout the $80^{\prime}$ s to date. Effects of exchange rate fluctuations in developing countries like Nigeria has received considerable attention and generated much debate. The debate focuses on the degree of fluctuations in the exchange rate had generated internal and external shock in Nigerian Economy. Exchange rate of a country plays a key role in international economic transactions because no nation can remain in autarky due to varying factor endowment (Azeez, et al., 2012).

Oladipupo and Onotaniyohuwo (2011) states that movements in the exchange rate have ripple effects on other economic variables such as interest rate, inflation rate, unemployment, money supply, etc. These facts underscore the importance of exchange rate to the economic well-being of every country that opens its doors to international trade in goods and services. The importance of exchange rate derives from the fact that it connects the price systems of two different countries making it possible for international trade to make direct comparison of traded goods. In other words, it links domestic prices with international prices. Opaluwa, Umeh, and Ameh (2012) opines that following the fluctuations of the naira in 1986, a policy induced by the Structural Adjustment Programme (SAP), the subject of exchange rate fluctuation has become a topical issue in Nigeria. This is because it is the goal of every economy to have a stable rate of exchange with its trading partners. In Nigeria, this goal was not reached in spite of the fact that the country embarked on devaluation to promote export and stabilize the rate of exchange. The failure to realize this goal subjected the Nigerian manufacturing sector to the challenge of a constantly fluctuating exchange rate. Exchange rate policies in developing countries are often sensitive and controversial, mainly because of the kind of structural transformation required, such as reducing imports or expanding non-oil exports, invariably imply a depreciation of the nominal exchange rate. Such domestic adjustments, due to their short-run impact on prices and demand, are perceived as damaging to the economy. Ironically, the distortions inherent in an overvalued exchange rate regime are hardly a subject of debate in developing economics that are dependent on imports for production and consumption (Dada \& Oyeranti, 2012).

In recent time, a study was carried out by Muriuki, et al (2013) which developed a model of foreign exchange exposure dependent on three variables, the firm's imports, exports and their effect on profits formulating the problem statement of the effects (if any) that variations in the exchange rate has in the financial performance of the selected listed companies in the Nairobi Stock Exchange for the period covering years 2001 to 2010. The study is to find out whether foreign exchange exposure is minimized where firms have been able to match their foreign currency revenues and costs leaving them with little net exposure.

This research paper was carried out by Enekwe, et al (2013). From current research, the issue of deciding on effective way to stabilize exchange rate of goods and services in manufacturing sector in Nigeria is one of the key elements of a firm's financial strategy. Therefore, proper care and attention need to be given while such decision is taken. Exchange rate of a country plays a key role in international economic transactions because no nation can remain in autarky due to varying factor endowment. The purpose of this paper is to know the effects of exchange rate fluctuations on manufacturing sector in Nigeria over a period of 25 years (1985 - 2010). 


\section{Methodology}

In order to determine if foreign exchange rate fluctuation impact on firms' performance the model for the study is hereby specified as follows:

ROI= EXR, INFL, INT, LIQ, LEV, GVE, DOP

The above model is hereby written in linear form as:

$\mathrm{ROI}=\mathrm{b}_{\mathrm{o}}+\mathrm{b}_{1} \mathrm{EXR}+\mathrm{b}_{2} \mathrm{INFL}+\mathrm{b}_{3} \mathrm{INT}+\mathrm{b}_{4} \mathrm{LIQ}+\mathrm{b}_{5} \mathrm{LEV}+\mathrm{b}_{6} \mathrm{GVE}+\mathrm{b}_{7} \mathrm{DOP}$

Where:

* ROI = RETURN ON INVESTMENT

It is expected that return on investment should be positive

$$
f^{i}(R O I)>0
$$

$\mathrm{EXR}=\mathrm{EXCHANGE} \mathrm{RATE}$

$$
f^{i}(E X R)>0
$$

It is expected that a favorable exchange rate will positively affect return on investment

INFL $=$ INFLATION RATE

$$
f^{i}(I N F)<0
$$

It is expected that high inflation rate will impede return on investment.

INT $=$ INTEREST RATE

$$
f^{i}(I N T)>0
$$

It is expected that an increase in interest rate will positively affect interest rate LIQ = LIQUIDITY RISK

$$
f^{i}(L I Q)>0
$$

It is expected that an increase in Liquidity rate will positively affect return on investment INT = LEVERAGE RISK

$$
f^{i}(L E V)>0
$$

It is expected that an increase in leverage risk will affect return on investment

\section{GVE $=$ GOVERNMENT EXPENDITURE}

$$
f^{i}(G V E)>0
$$

It is expected that an increase in Government Expenditure will affect return on investment DOP $=$ DEGREE OF OPENNESS 


$$
f^{i}(D O P)>0
$$

It is expected that increase in degree of openness should vary in a direct proportion to the return on investment.

Table 1.3: Descriptive Statistics for Dependent and Explanatory Variables

\begin{tabular}{|c|c|c|c|c|c|c|c|c|}
\hline & ROI & EXR & INFL & INT & LIQ & LEV & GVE & DOP \\
\hline Mean & 12.05000 & 223.5550 & 11.27500 & 6.742500 & 19.78000 & 19.74750 & 457.2261 & 11.13750 \\
\hline Median & 11.79000 & 200.0000 & 11.40000 & 6.865000 & 19.09500 & 18.29000 & 412.3790 & 9.900000 \\
\hline Maximum & 23.80000 & 364.0000 & 15.00000 & 7.750000 & 22.90000 & 24.85000 & 671.5750 & 16.60000 \\
\hline Minimum & 4.400000 & 150.2900 & 8.000000 & 5.690000 & 18.24000 & 17.95000 & 205.6780 & 8.600000 \\
\hline Std. Dev. & 6.621688 & 78.18858 & 2.592337 & 0.779931 & 1.587235 & 2.380610 & 144.2428 & 2.605597 \\
\hline Skewness & 0.441666 & 0.751858 & -0.011326 & -0.080580 & 0.775631 & 1.112467 & 0.143002 & 0.991580 \\
\hline Kurtosis & 1.962196 & 2.063800 & 1.476953 & 1.454516 & 2.301121 & 2.917889 & 2.448570 & 2.810608 \\
\hline Jarque-Bera & 5.571940 & 9.412903 & 6.960553 & 7.243477 & 8.684538 & 14.87123 & 1.157619 & 11.90638 \\
\hline Probability & 0.061669 & 0.009037 & 0.030799 & 0.026736 & 0.013007 & 0.000590 & 0.560565 & 0.002598 \\
\hline Sum & 867.6000 & 16095.96 & 811.8000 & 485.4600 & 1424.160 & 1421.820 & 32920.28 & 801.9000 \\
\hline Sum Sq. Dev. & 3113.120 & 434055.3 & 477.1350 & 43.18875 & 178.8714 & 402.3788 & 1477225 . & 482.0288 \\
\hline Observations & 72 & 72 & 72 & 72 & 72 & 72 & 72 & 72 \\
\hline
\end{tabular}

Source: Extracted from SPSS output, 2018.

Table 1.3 shows that the mean value for firms' performance (ROI) is 12.05 , for the EXR and INF were having an average value of 233 and 11.6 respectively. Interest Rate (INT) has an average value of about $6.74 \%$. The minimum value for firms' performance (ROI) is 4.40 while for the maximum is 23.8 the minimum value of EXR 364 while the maximum is 160 , INF has minimum value of 10.90 while for the maximum is 15.01 , and the minimum value of INT is 11.34 and maximum is 14.81 .

It is observed that the EXR has the highest standard deviation among the independent variables that are significant at $5 \%$ level and therefore it shows that the INT has the least contribution to the dependent variable. The skewness values were all close to 0 and 1 except for INT implying higher than normal, else the data is considered to be tolerably mild and normally distributed. Therefore the result from the two normality substantiates the validity of the regression result.

On the other hand, the outputs of the descriptive statistics indicated that the maximum of liquidity risk is $51.8 \%$ while the minimum one is $54.1 \%$. This indicates that the firm's liquidity position is above average. The degree of openness and the government expenditures shows a mean value of 230.467 and 102.466 respectively. The leverage risk also has a mean value of 409.400 , and the maximum and minimum value 
of 254 and 746 respectively. But the standard deviation value is 183.27 which the highest value among independent variables.

\subsection{Model Specification}

In order to account for the determinants of capital adequacy in the banking sub-sector of the Nigeria economy, the model for the study is hereby specified as follows:

ROI $=$ EXR, INFL, INT, LIQ, LEV, GVE, DOP

$\mathrm{ROI}=\mathrm{b}_{\mathrm{o}}+\mathrm{b}_{1} \mathrm{EXR}+\mathrm{b}_{2} \mathrm{INFL}+\mathrm{b}_{3} \mathrm{INT}+\mathrm{b}_{4} \mathrm{LIQ}+\mathrm{b}_{5} \mathrm{LEV}+\mathrm{b}_{6} \mathrm{GVE}+\mathrm{b}_{7} \mathrm{DOP}$

Table 1.3 1: Panel Least Square of the Impact of Exchange Rate on Firm Performance.

\begin{tabular}{|c|c|c|c|c|}
\hline \multicolumn{5}{|c|}{ Dependent Variable: ROI } \\
\hline \multicolumn{5}{|c|}{ Method: Panel Least Squares } \\
\hline \multicolumn{5}{|c|}{ Date: $04 / 31 / 18$ Time: $13: 15$} \\
\hline \multicolumn{5}{|l|}{ Sample: 20092016} \\
\hline \multicolumn{5}{|l|}{ Periods included: 8} \\
\hline \multicolumn{5}{|c|}{ Cross-sections included: 9} \\
\hline \multicolumn{5}{|c|}{ Total panel (balanced) observations: 72} \\
\hline Variable & Coefficient & Std. Error & t-Statistic & Prob. \\
\hline $\mathrm{C}$ & 91.48114 & 1.220011 & 7.520012 & 0.0000 \\
\hline EXR & -0.012552 & 5.230015 & -2.400012 & 0.0000 \\
\hline INFL & -2.123517 & 2.340013 & -9.060012 & 0.0000 \\
\hline INT & 6.494622 & 8.060003 & 8.060012 & 0.0000 \\
\hline LIQ & -4.730966 & 5.950013 & -7.940012 & 0.0000 \\
\hline LEV & 2.447691 & 3.190013 & 7.670012 & 0.0000 \\
\hline GVE & -0.079276 & 6.930015 & -1.140013 & 0.0000 \\
\hline DOP & -1.345231 & 4.390013 & -3.060012 & 0.0000 \\
\hline R-squared & 1.000000 & \multicolumn{2}{|c|}{ Mean dependent var } & 12.05000 \\
\hline Adjusted R-squared & 1.000000 & \multicolumn{2}{|c|}{ S.D. dependent var } & 6.621688 \\
\hline S.E. of regression & 2.500012 & \multicolumn{2}{|c|}{ Akaike info criterion } & -50.48404 \\
\hline Sum squared resid & 4.010022 & \multicolumn{2}{|c|}{ Schwarz criterion } & -50.23108 \\
\hline Log likelihood & 1825.425 & \multicolumn{2}{|c|}{ Hannan-Quinn criter. } & -50.38334 \\
\hline F-statistic & 7.090025 & \multicolumn{2}{|c|}{ Durbin-Watson stat } & 2.386536 \\
\hline Prob(F-statistic) & 0.000000 & & & \\
\hline
\end{tabular}

Source: Author's computation 2018

\section{Result and Discussion}

The Table 1.3.1 shows the relationship between Return on Investment (ROI) and other variables in the model. ROI is known as the dependent variable and other variables in the model are known as the independent variables. From the above regression result, we can deduced that there is a negative relationship between Exchange rate (EXR) of -0.012552 and Return on Investment as most of the banks are involved in exchange rate transactions. This implies that a unit increases in exchange rate of 0.012552 will bring about a corresponding fall in Return on Investment (ROI). The inflation rate (INF) shows a negative of 2.123517 with ROI. This however, corroborate with the apriori expectation that inflation has a negative impact on ROI. The interest rate (INT) has 6.494622 coefficient relationship with ROI. This simply means that one percent increase in INT will lead to a corresponding increase in ROI of 6.494622. We can deduce that liquidity risk (LIQ) has a negative coefficient of -4.730966 with ROI. This 
means that one percent increase in LIQ will lead to a corresponding fall in ROI. The relationship between leverage (LEV) and ROI is positive. This indicates that an increase of one unit in leverage risk to ROI will lead to the same increase of 2.447691. The government expenditure (GVE) variable has a negative impact on ROI of -0.079276. This may arise as a result of the negative impact of previous government in Nigeria such as the military rule. The regression result shows a negative relationship between Return on Investment and degree of openness (DOP) of -1.345231. This means that one percent increase in DOP will lead to a corresponding fall in ROI. This does not corroborate with the a priori expectation in chapter three that degree of openness add to economy value and investment. When the economy is open there tends to be foreign direct investment.

In the result, the coefficient of determination is very high. It shows that about 100 percent of the total variations in Return on Investment (ROI) are explained by all the independent variables in the model. The adjusted $\mathrm{R}^{2}$ also indicates that about 100 percent of the total variations in ROI are explained by the model. The F-statistic is significant at 5 percent critical level. It indicates that the joint variations of the model are significant. However the Durbin Watson value indicates a presence of positive autocorrelation and this might be the reason for result. The F statistic of the model is 7.090025 while the probability of F-statistics is 000000. This implies that there is a significant relationship between exchange rate and Return on Investment. The Durbin-Watson value is 2.386 .

\subsection{Test of Hypothesis Using T-Test on Table 1.3.1}

The t-test value is assume to be the average weighted and can be used to test hypothesis. We assume that T-tabulated is $5 \%(0.05)$.

We reject $\mathrm{H}_{0}$ if T-calculated $>$ T-tabulated. T-calculated can be obtained from the regression table above.

\section{Hypothesis I}

$\mathrm{H}_{\mathrm{o}}$ : Exchange rate does not significantly affect firms' performance. T-calculated $=-2.400012$.

$-2.400012<0.05$ we conclude that EXR is significant and therefore we reject the null hypothesis and accept the alternative hypothesis that Exchange rate significantly affect firms' performance.

\section{Hypothesis II}

$\mathrm{H}_{\mathrm{o}}$ : Inflation does not significantly affect firms' performance.

$-9.060012<0.05$ we reject the alternative hypothesis and accept the null hypothesis that Inflation does not significantly affect ROI.

\section{Hypothesis III}

$\mathrm{H}_{\mathrm{o}}$ : Interest Rate does not significantly affect firms’ performance.

$-8.060012<0.05$ we conclude that INT is significant and therefore we reject the null hypothesis and accept the alternative hypothesis that INT significantly affect firms' performance.

\section{Hypothesis IV}

$\mathrm{H}_{\mathrm{o}}$ : Liquidity Risk does not significantly affect firms’ performance.

$-7.940012<0.05$ we conclude that LIQ is significant and therefore we reject the null hypothesis that LIQ does not significantly affect firms' performance (ROI) and accept the alternative hypothesis that LIQ affect ROI.

\section{Hypothesis V}

$\mathrm{H}_{\mathrm{o}}$ : Leverage Risk does not significantly affect firms’ performance. 
$-7.670012<0.05$ we conclude that LEV is significant and therefore we reject the null hypothesis and accept alternative that LEV significantly affect firms' performance (ROI).

\section{Hypothesis VI}

$\mathrm{H}_{\mathrm{o}}$ : Government Expenditure does not significantly affect firms’ performance.

$-1.140013<0.05$ we conclude that GVE is significant and therefore we reject the null hypothesis that GVE does not significantly affect firms' performance (ROI) and accept alternative hypothesis.

\section{Hypothesis VII}

$\mathrm{H}_{\mathrm{o}}$ : Degree of Openness does not significantly affect firms' performance.

$-3.060012<0.05$ we reject the alternative hypothesis and accept the null hypothesis that Degree of Openness does not significantly affect ROI.

\section{Conclusion}

From the above analysis; it was observed that there is significant relationship between exchange rate and return on investment in Nigeria. Exchange rate is considered having negative impact on investment, any ineffectiveness in management strategy will constitute a huge problem i.e. exchanges rate fluctuations can cause huge problem that affect the affairs of the firms. Therefore the findings between exchange rate and firm performance are based on the decisions taken from the test of hypothesis. From the test of hypothesis above, it was deduced that exchange rate affect firm performance hence there is an impact of exchange rate fluctuations on firm performance. The liquidity risk, inflation rate, government expenditures and degree of openness shows a negative relationship with return on investment. The test of hypothesis on all the independent variables shows that the null hypothesis should be rejected and the alternative hypothesis should be accepted.

Based on findings, there is a strong and negative relation between exchange rate and firm's performance in Nigeria. Also an increase in interest rate and inflation rate bring about an instability of investment in the market and thus affect negatively on firm's financial performance. The leverage and liquidity risk measures the risk faced by banks and the degree of openness shows how open the economy is to investment. The use of government expenditure in a study of this nature helped in identifying government impact in encouraging investment in Nigeria. The increase in return on investment which represents firm's performance goes with the impact of some variables.

The study concluded that if negative relationship persist between exchange rate and firm's performance, unfavorable economic environment will occur which broadly affect the Nigeria economic stability. The study therefore recommend government and private partnership for effective management of exchange rate fluctuations in Nigeria.

\section{References}

Abdullahi, F.Z, Ladan, S \&Bakari, H.R (2017). Foreign private investment and Economic growth in Nigeria.A co integrated VAR and Granger causality analysis" CBN Journal, 15(3), 2345-2378.

Ajanthan, A. (2013). A Nexus between Liquidity \& Profitability: A Study of Trading Companies in Sri Lanka. European Journal of Business and Management, 5(7), 221-237.

Archarungroj, P. \& Hoshino, Y. (1998). The Impact of Firm Size on Export Performance and Attitudes: An Empirical Study on Thailand Exporters. Japanese Journal of Administrative Science, 12(2), 79 - 88.

Asher, O.J. (2016). The impact of exchange rate fluctuation on the Nigeria Economic growth (1980 - 2010).Unpublished B.Sc project department of Economics, Caritas University Emene Enugu, Enugu State. 
Asika N. (2006). Research methodology in behavioral sciences, Lagos, longman Nigeria Plc.

Azeez, B.A.Kolopo, F.T \&Ajayi, L.B. (2012).Effect of exchange rate volatility on macroeconomic performance in Nigeria Interdisciplinary Journal of contemporary Research in Business, 4(1), $149-155$.

Bagchi, B. \&Chakrabarti,J. (2012).Modeling liquidity management for Indian FMCG firms. International Journal of Commerce and Management, 2(4), 334-354.

Bartelsman, E., Scarpetta, S. \&Schivardi, F. (2015). Comparative analysis of firm demographics and survival: evidence from micro-level sources in OECD countries. Journal of Industrial and Corporate Change 3(2), 365-391.

Bellone, F., Musso, P., Nesta, L. \&Quere, M. (2017).Market selection along the firm life cycle. Industrial and Corporate Change, 17(4), 753-777.

Brown, C. \& Medoff, J.L. (2003).Firm age and wages.Journal of Labor Economics, 23(3), 677-697

Campbell, J.Y. and Vuolteenaho, T. (2017).Inflation illusion and stock prices.American Economic Review, 94(2), 19-23.

Dada, E.A \&Oyeranti, O.A. (2012).Exchange rate and macroeconomic aggregates in Nigeria.Journal ofEconomics and Sustainable development, 3(2), 93 - 101.

Eljelly, A. (2014). Liquidity-Profitability Tradeoff: An empirical Investigation in an Emerging Market. International Journal of Commerce \& Management, 14(2), 48 - 61.

Foster, J.B. \&Magdoff, F. (2009). The Great Financial Crisis: Causes andConsequences. New York: Monthly Review Press.

Garcia-Teruel, Juan \& Martinez-Solano, Pedro (2007).Effects of working capital Management on SME profitability. International Journal of Managerial Finance, 5(3), 56-59.

Garnsey, E., Stam, E. and Heffernan, P. (2006). New firm growth: Exploring processes and paths. Industry and Innovation 13(1), 1-20.

Lewellen, J (2014). Predicting returns with financial ratios. Journal of Financial Economics, 7(4), 209-235.

Majumdar, S.K. (2017). The Impact of Size and Age on Firm-Level Performance: Some Evidence from India, Review of Industrial Organization, 12 (2), 231-241.

Oladipupo, A.O.\& Onotaniyohuwo, F.O. (2011).Impact of exchange rate on balance of payment in Nigeria.African research review: An international multidisciplinary Journal, Ethiopia, 5(4), 73 - 88.

Opaluwa, D., Umeh, J.C., \&Ameh, A. A. (2012).The effect of exchange rate fluctuations on the Nigerian manufacturing sector.African Journal of Business Management, 4(14), 2994 2998.

Owolabi, A.U \&Adegbite, T. A. (2017).The effect of foreign exchange regimes on industrial growth in Nigeria.Global Advanced Research Journal of Economic, Accounting and Finance, $1(1), 1-8$.

Ozgulbas, N., A.S. Koyuncugil\&Yilmaz, F. (2006), “Identifying the Effect of Firm Size on Financial Performance of SMEs", The Business Review, Cambridge, 6 (1), 162-167.

Raheman, A.\&. Nasr, M. (2013). Working Capital Management and Profitability - Case of Pakistani Firms. International Review of Business Research Papers, 3(2), 275 - 296.

Smith, K.(2014). Profitability versus liquidity tradeoffs in working capital management" in Readingson the management of working capital, K.Smith (ed.), St Paul: West PublishingCompany, 549-562.

Zariyawati, A. M. \&Annuar, N. M., Taufiq, \& Rahim, A.S. (2010). Working capital management and corporate performance: Case of Malaysia. Journal of Modern Accounting and Auditing,5(11), 234-237. 